\title{
FRONT SYSTEMS AND SUSPENDED SEDIMENT DYNAMICS OF LINGDINGYANG BAY IN THE SUMMER, PEARL RIVER ESTUARY, SOUTH CHINA
}

\author{
WEI, H. - ZHU, L.* \\ School of Civil Engineering and Transportation, South China University of Technology, \\ GuangZhou 510641, China \\ (e-mail:772365131@qq.com-H.Wei) \\ *Corresponding author \\ e-mail:lszhu2000@vip.163.com \\ (Received $8^{\text {th }}$ Mar 2019; accepted 21 ${ }^{\text {st }}$ May 2019)
}

\begin{abstract}
Lingdingyang (LDY) is an important navigation waterway for the Pearl River delta (PRD), and an important passage for fresh water and sediments entering the sea. The data and hydrological information, including SSC, current, water level, and bed sediment was collected on July 6-7, 2005 to analyze its characteristics, and sediment transport. The data was entered into a hydrodynamic simulation model used to characterize the processes of sedimentation and morphological evolution of the Pearl River estuary (PRE). LDY was divided into three sub-areas dominated by (1) west shoal area, (2) jet flow area, and (3) saline water area. Navigation engineering and other human activities result in an increase of deposition rate. These characteristics can be greatly accelerated by human activities. Field data and model results indicate that the front system, composed of the shear front and tide incursion front, has an important impact on sedimentation.
\end{abstract}

Keywords: fresh water, a hydrodynamic simulation model, navigation engineering, deposition rate, silting characteristics

\section{Introduction}

The Pearl River delta in southern China is one of the most complex deltas in world. It is a typical river network delta including three converging rivers and eight outlets emptying to the sea (Allen et al., 1980; Daniel et al., 2018). The three rivers are the West River (WR), North River (NR) and East River (ER). The eight outlets are the Humen (HM), Jiaomen (JM), Hongqimen (HQM), Hengmen (HM), Modaomen (MDM), Jitimen (JTM), Hutiaomen (HTM), and Aimen (AM). Humen and Aimen are tidal-dominated estuaries. The other six are fluvial-dominated mouths. Humen, Jiaomen, Hongqimen and Henmen, also called the eastern four mouths, empty into the tidal-dominated estuary of Lingdingyang (LDY) bay. LDY is characterized by three shoals and two channels, which refer to the West, Central, and East shoals, and the East, and West channels (Ren et al., 2001; Nwankwoala, 2019). The west shoal is an important buffer between Lingdingyang bay and the eastern three river mouths (JM HQM and HM). It is also a water passage carrying sediment from the three river mouths and a protecting barrier for the Lingding navigation channel.

Tides of LDY belongs to irregular semidiurnal mixing tides, low tides and high tides occurring two times a day, with a tidal coefficient of $0.94 \sim 1.77$. The LDY tidal range is less than $2 \mathrm{~m}$, and due to the influence of the trumpet shaped topography, increasing tidal range from outer bay to head. Because of runoff, the tidal range descends from HUM to HM. Outer sea area, greatly affected by tide, ebb duration is approximately equal to flood duration. River outlet, affected by runoff, ebb duration is 
longer than that of the flood. The flood and ebb duration ratio, is $0.93 \sim 1.26$ in dry season, $1.05 \sim 1.55$ in wet season.

An estuary is a semi-enclosed coastal body of water, which is connected to the open sea, extending to a river to the limit of tidal influence, and within which sea water is diluted with fresh water derived from land drainage (Cameron et al., 1963 ; Van Maren et al., 2016; Dalrymple et al., 1992; Dai et al., 2013, 2012; 2011 a; Rahim et al., 2018). The estuary acts as a filter between the land and the ocean (Dai et al., 2011b), and sediment traps, retaining a proportion of their river and marine borne sediment load in the intertidal zone (Dellwig et al., 2000; Sharjeel et al., 2019).

Dynamics of estuarine suspended sediments are very complex and strongly variable over time scales ranging from seconds to years (Dyer et al., 1988). In tidal estuaries, fine sediment dynamics is often related to the Mechanism of turbidity maximum zone (Fettweis et al., 2012; Ferriera et al., 1997; Grabemann et al., 1997; Hume and Herdendorf, 1988; Omini and Akpang, 2018). Subsequently, many literatures studied mainly TMZ and its response to estuarine forces (Jalón-Rojas et al., 2017, 2015; Jia et al., 2013; Chen et al., 1999; Largier, 1992; Shi, 2010). Another important process is estuarine front system, which has been given more attentions to since 1990's (Williams et al., 2015; Li, 2004; Qiao, 2018). Fronts may exert control on the surface and water column sediment and pollutant partitioning and also on the distribution and persistence of bed load transport pathways ( $\mathrm{Li}$ et al., 2003). Both estuarine circulation and tidal asymmetry are of great importance to the fine sediment processes (Lick et al., 1994), and the two processes are very obvious in front system.

Previous research on sediments of LDY has involved the development of a mathematical tidal model (Lick et al., 1995), physical model (Lu et al., 2005), ground sampling surveys and theoretical analysis (Le Hir et al., 2001; Pinckney and Dustan, 1990; Pritchard, 1967). Estuarine front is an important dynamical process, which exerts an influence on sedimentation (Reeves and Duce, 2001; Sarwar et al., 2019). According to dynamics, there are four types fronts in LDY, tidal intrusion front, head land front, oblique plume front, and shoal front (Ren et al., 2010).

As there are enough gradients of density and velocity in waters, the fronts would be formed. Shelf saline water intruding there that make the difference of sediment dynamic process and sediment grain distribution in spatial, i.e. coarse, fine, and fairly coarse from upper to lower regions (Ren et al., 2006; Sarker et al., 2019).

According to geomorphology, LDY can be divided into three geo-systems, tide inlet of HM (Northwest LDY), fluvial dominated area (West LDY), shelf saline water area (south LDY) (Duck and Wewetzer, 2001). The boundary of these power structures is the interface between two kinds of fronts, namely the continental shelf front and shear front.

This paper focuses on the characteristics and sedimentation, as well as impacts of recent silting. Our goal was to understand the processes associated with front system and human activity leading to sedimentation during the wet season (Jiang et al., 2018). The LDY is dominated by runoff and most sediment comes from eastern outlets of PRD during the wet season. The system of shoals and channels plays an important role in sediment transportation and front systems also result from the geography of the system (Savenije, 2006). Human activity has an enormous impact on sedimentation and this is reflected in system evolution. 


\section{Materials and methods}

\section{Morphology}

LDY is a funnel-shaped estuary located on the east side of the PRD (Fig. 1). The width of bay head is $4 \mathrm{~km}$, width of bay mouth is $65 \mathrm{~km}$, longitudinal length is $60 \mathrm{~km}$, and total area $2100 \mathrm{~km}^{2}$.

The West shoal is located in the west side of the Lingding navigation channel. It receives water and sediments from Hengmen, Hongqimen, Jiaomen, and its area is $185 \mathrm{~km}^{2}$. In the 1940's, floods scoured out the underwater levee, which gradually eroded then become the North branch. The North branch plays an important role in sediment transportation between the South branch and the Lingding channel (Fig. 2). The North branch acts as a flood diversion channel during the flood season, accelerates the flood discharge, and reduces flood pressure on Hongqimen and Henmen. The depths of North branch, South branch, and Lingding channel are 3-5 m, 7-8 m and $15 \mathrm{~m}$ respectively. Using the method of dynamic geomorphology, the channel system of the shoal can be divided into flood-dominated channels (flood channel) and ebb-dominated channels (ebb channel) in part B of Figure 1. During the dry season, tidal dynamics dominates the shoal, and the net transportation of sediments differs in the two channel types. In the wet season, the entire shoal is dominated by river dynamics and the net transportation of sediments seaward is consistent among the channels. Because the main river bifurcates easterly, the river dynamics weaken. The middle and lower segments evolve from an ebb channel to a flood channel in part B of Figure 1.

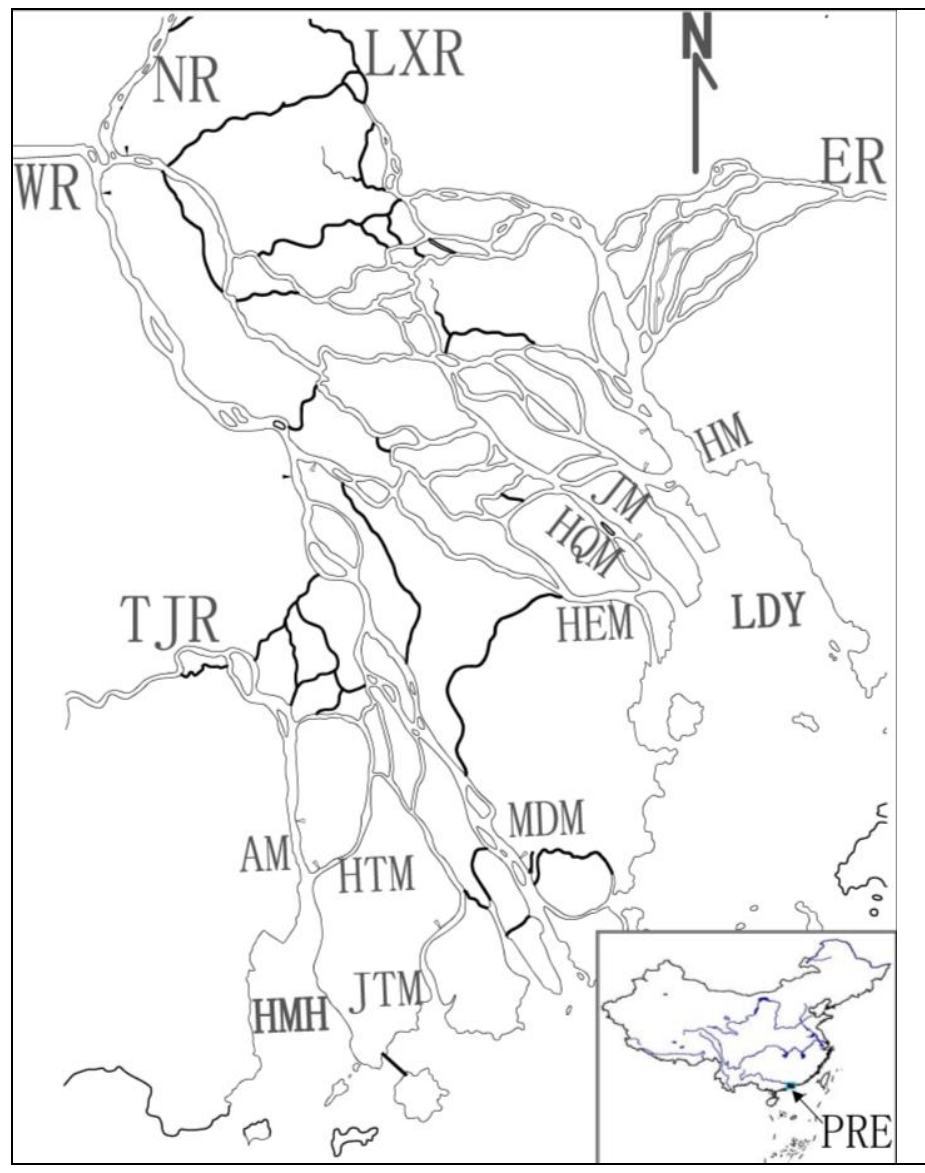

Figure 1. Sketch of PRE 


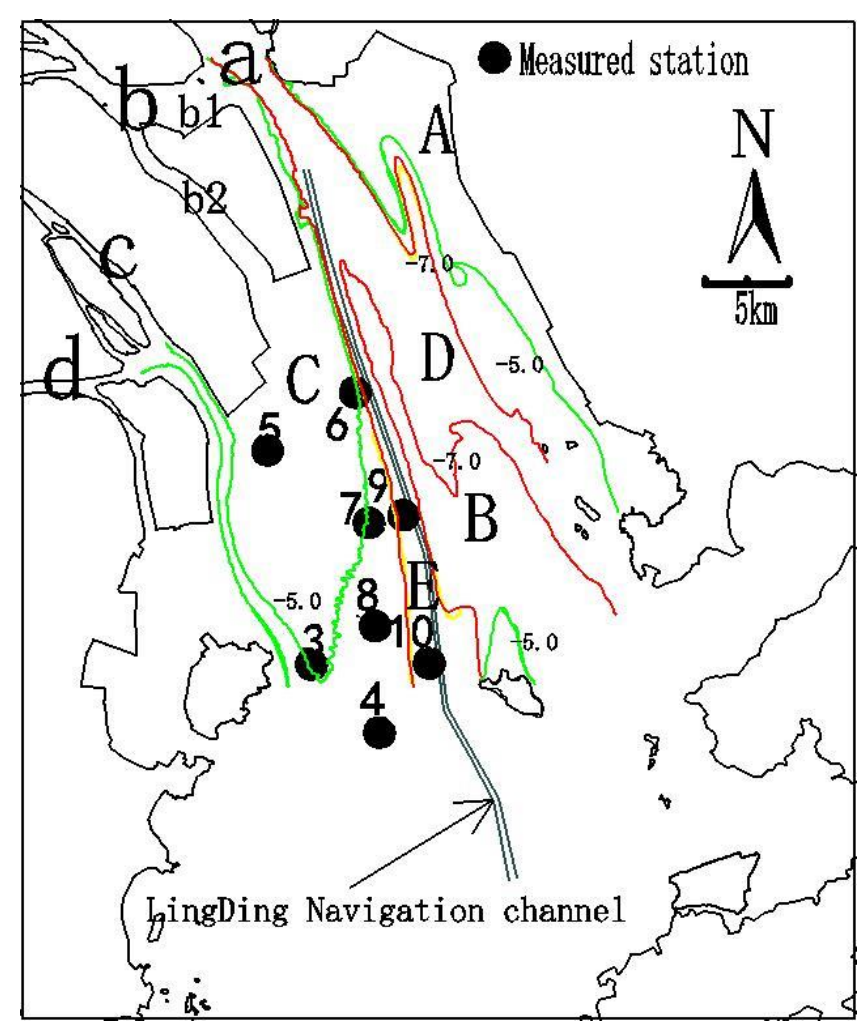

Figure 2. Sketch and measured station of study area (A: East tidal flat, B: Central tidal flat, C: West tidal flat, D: East channel, E: West channel; a: Humen, b: Jiaomen, c: Hongqimen, $d$ : Hengmen, b1: north branch, b2: south branch)

\section{Hydrology and sediment}

The Pearl River has a mild subtropical monsoon climate with relatively abundant precipitation. Mean annual rainfall is $1526 \mathrm{~mm}$ and this is concentrated in 9 months which, together, account for $80 \%$ of the annual rainfall. SSC of the Pearl River is the lowest of the seven major China rivers. However, sediment transport capacity from runoff is large. Average sediment transport capacity is 85.7 million tons, which is the third largest amount for China rivers. The average SSC of Gaoyao station of West River is $0.320 \mathrm{~kg} / \mathrm{m}^{3}$.

PRE has an irregular semidiurnal tide, and the tidal range is small. The mean tidal range is $1.60 \mathrm{~m}$ and the maximum tidal range is $3.36 \mathrm{~m}$. The PRE is a typical weak tidal estuary. Flood tide (current that moves toward shore) duration lasts $7 \mathrm{~h}$ and $20 \mathrm{~min}$ and mean ebb duration lasts $5 \mathrm{~h}$ and $30 \mathrm{~min}$. The flood tide duration during the wet season is shorter than that in the dry season.

LDY is a micro-tidal estuary. With a funnel-shaped topography, the tidal energy converges and tidal range increases from mouth to head. Average ranges of Chiwan, Sanbanzhou, and Dahu stations were $1.36 \mathrm{~m}, 1.59 \mathrm{~m}$, and $1.69 \mathrm{~m}$ respectively. Tides are irregular semidiurnal mixed with ebbing and flooding twice a day. SSC during the wet season is larger than that of dry season, and SSC varies with ebb and flood (Table 1). In the wet season, fine sand is the major component of bed sediment at Hongqimen and Jiaomen. Particle size at these two outlets ranges between $0.1 \mathrm{~mm}$ and $0.5 \mathrm{~mm}$, which occupies $90 \%$ of the total. The bed sediment of Humen is composed of medium coarse sand with a median particle diameter of $0.244 \mathrm{~mm}$. 
Table 1. SSC of eastern four outlets (unit, $\mathrm{kg} / \mathrm{m}^{3}$ )

\begin{tabular}{c|c|c|c|c|c}
\hline \multirow{2}{*}{ Outlet name } & \multirow{2}{*}{ Season } & \multicolumn{2}{|c|}{ Flood } & \multicolumn{2}{c}{ Ebb } \\
\cline { 3 - 6 } & & Average & Maximum & Average & Maximum \\
\hline \multirow{2}{*}{ Henmen } & Dry season & 0.029 & 0.071 & 0.031 & 0.059 \\
& Wet season & & & 0.570 & 0.670 \\
\hline \multirow{2}{*}{ Hongqimen } & Dry season & 0.021 & 0.050 & 0.021 & 0.034 \\
& Wet season & & & 0.720 & 0.830 \\
\hline \multirow{2}{*}{ Jiaomen } & Dry season & 0.044 & 0.110 & 0.035 & 0.074 \\
& Wet season & & & 0.420 & 0.610 \\
\hline \multirow{2}{*}{ Humen } & Dry season & 0.083 & 0.160 & 0.074 & 0.130 \\
& Wet season & 0.130 & 0.190 & 0.200 & 0.310 \\
\hline
\end{tabular}

\section{Data}

We used the data of the second phase project of Zhongshan port. Synchronous hydrology sediment testing was completed by the hydrology and Water Resources Survey Bureau of the Yangtze River Water Conservancy Committee.

The survey period included tidal cycles from July 6 to July 7 in 2005. Fourteen boats are used for fixed-point measures, and measured items included velocity, SSC, and salinity. Three water level stations were established. The scale of the topographic survey was 1:5000. Figure 2 shows the sites of the measuring stations and bed sediment sample points.

Hydrological testing at fixed stations was done by using a conventional current meter that was fixed to a boat. SSC samples were obtained by using the $2000 \mathrm{CC}$ horizontal type sampler once per hour. If the depth was greater than $5 \mathrm{~m}$, we used the six point method (surface, $0.2 \mathrm{~h}, 0.4 \mathrm{~h}, 0.6 \mathrm{~h}, 0.8 \mathrm{~h}$, bottom), or the three point method $(0.2 \mathrm{~h}$, $0.6 \mathrm{~h}, 0.8 \mathrm{~h})$.

Suspended particles were analyzed using a centrifugal sedimentation particle size distribution instrument. We sampled bed sediments for particle size analysis using a cone type sampler, ensuring that the dry weight exceeded $50 \mathrm{~g}$. The distance between two samples sites is less than $3 \mathrm{~km}$. Analysis of bed sediment was done with a sonic vibration automatic sieving particle size analyzer and wide particle size analyzer. Salinity was determined using an electrode salinometer.

\section{Mathematical model}

The paper used Delft3D to model current, salinity, sediments. Delft Hydraulics has developed a unique, fully integrated computer software suite for a multi-disciplinary approach and 3D computations for coastal, river and estuarine areas.

It can carry out simulations of flows, sediment transports, waves, water quality, morphological developments and ecology. It has been designed for experts and nonexperts alike. The Delft3D suite is composed of several modules, grouped around a mutual interface, while being capable to interact with one another. Delft3D-FLOW, which this manual is about, is one of these modules. Delft3D-FLOW is a multidimensional (2D or 3D) hydrodynamic (and transport) simulation program which calculates non-steady flow and transport phenomena that result from tidal and meteorological forcing on a rectilinear or a curvilinear, boundary fitted grid. 
In order to model the hydrodynamics and cohesive sediments, a model covering the eight outlets and outer sea was established. The computed area was divided into 2050000 cells. The smallest side length in these cells was $10 \mathrm{~m}$, and the largest was $1000 \mathrm{~m}$. It is depth chart of LDY (Fig. 3). The model setup is shown in the following figure (Fig. 4), Model correction in the following figure (Fig. 5). It is the main modelling parameters for cohesive sediments (Table 2).

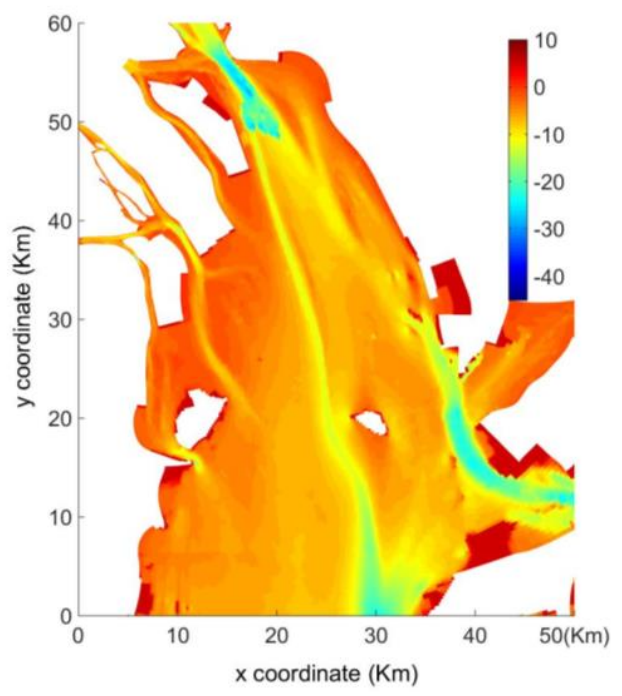

Figure 3. Depth chart of LDY

Table 2. Model parameters for cohesive sediments

\begin{tabular}{c|c|c}
\hline Parameter & Number & Units \\
\hline Setting velocity & $0.06-0.20$ & $\mathrm{~mm} / \mathrm{s}$ \\
Bed shear stress of sedimentation & $0.30-.0 .50$ & $\mathrm{~N} / \mathrm{m}^{2}$ \\
Bed shear stress of erosion & $0.55-0.80$ & $\mathrm{~N} / \mathrm{m}^{2}$ \\
Erosion parameter & $1.2 \mathrm{e}-4--1.8 \mathrm{e}-4$ & $\mathrm{~kg} / \mathrm{m}^{2} / \mathrm{s}$ \\
Initial layer thickness & 0.1 & $\mathrm{~m}$ \\
\hline
\end{tabular}

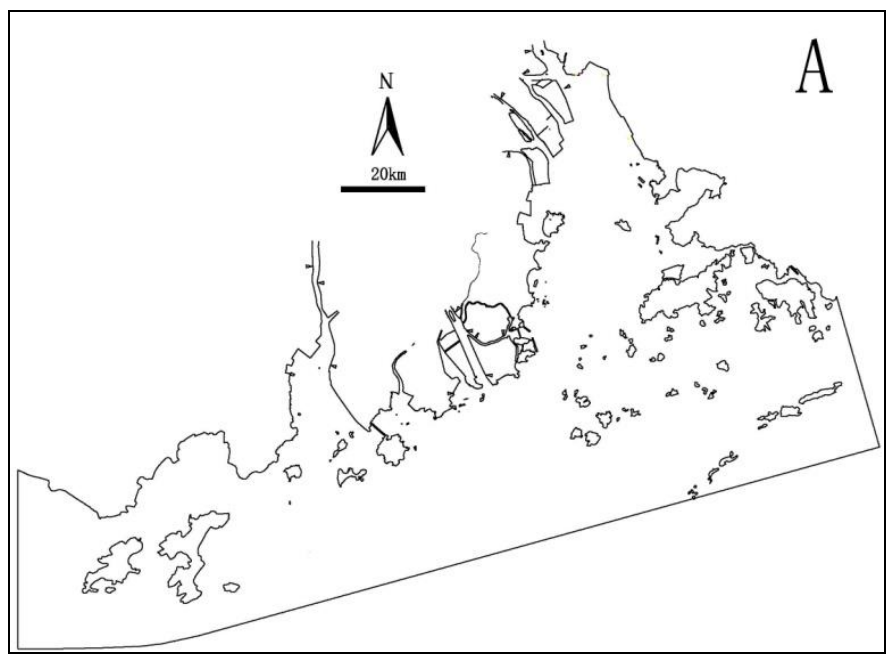




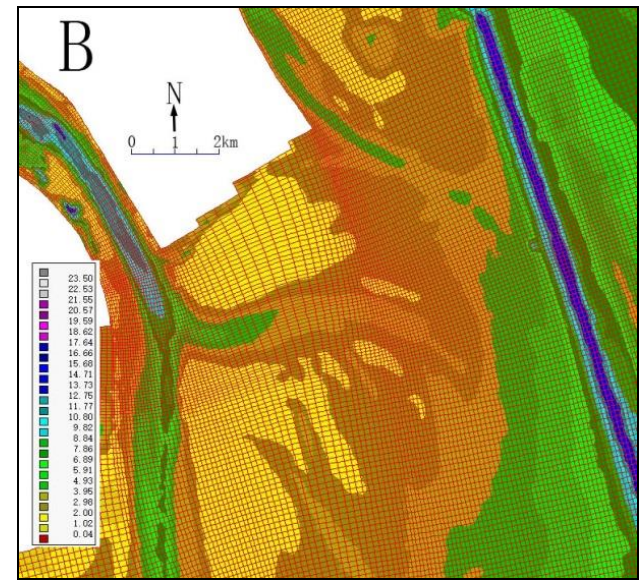

Figure 4. Model area (A) and local grid configuration (B)
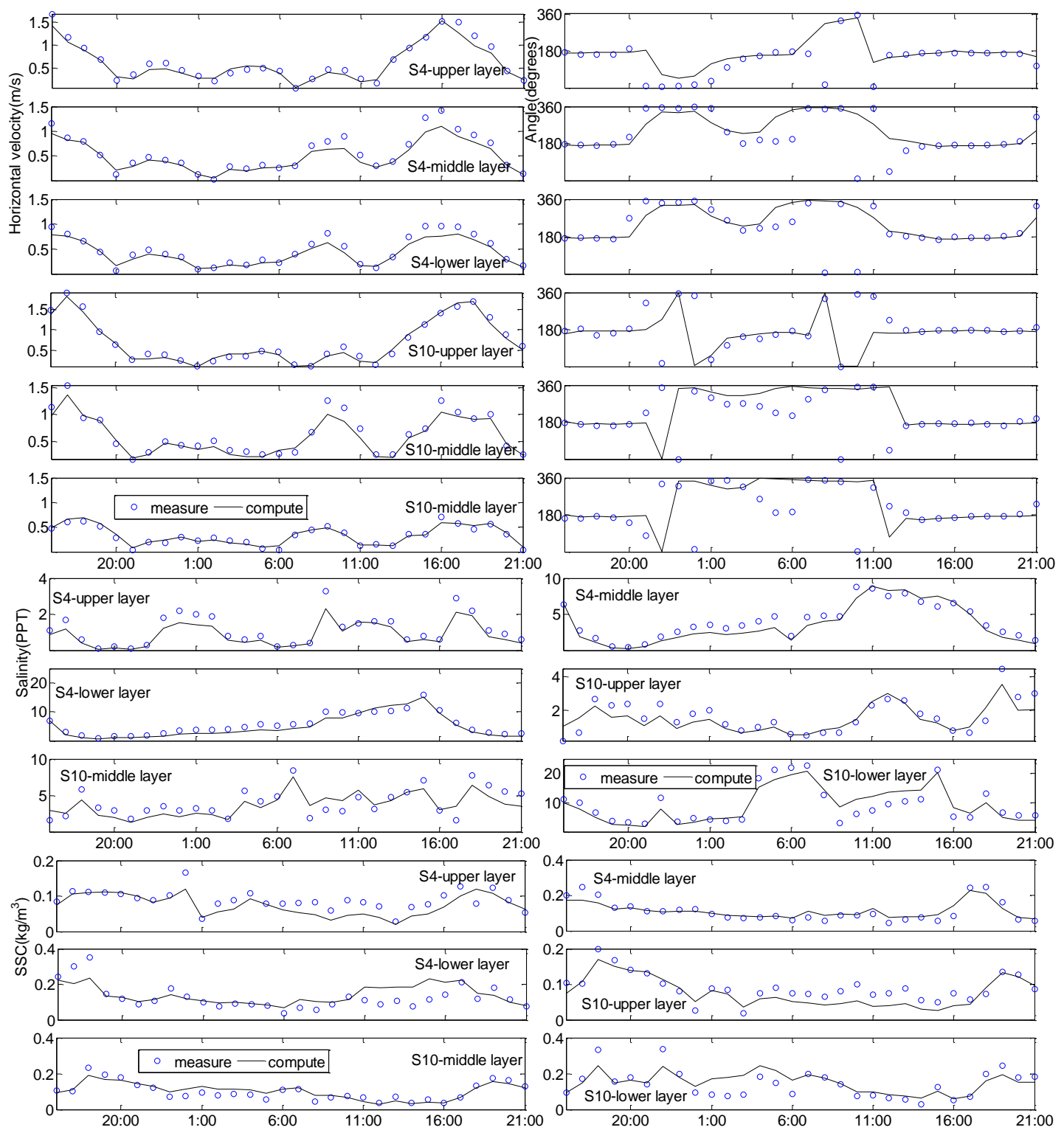

Figure 5. Model calibration figures

APPLIED ECOLOGY AND ENVIRONMENTAL RESEARCH 17(4):8465-8484.

http://www.aloki.hu • ISSN 15891623 (Print) • ISSN 17850037 (Online)

DOI: http://dx.doi.org/10.15666/aeer/1704_84658484

(c) 2019, ALÖKI Kft., Budapest, Hungary 


\section{Results}

\section{Hydrodynamic characters}

In wet season, LDY is dominated by discharge from runoff, and Salinity of LYD except a small south fraction is zero. The chart of modeling current field of model is shown in Figure 6. In flood tide duration, the velocity is very small in LDY, even no flood tide current in outlets. But, the ebb tide flow is very large, reaching above $1.0 \mathrm{~m} \mathrm{~s}^{-1}$ (Fig. 6).
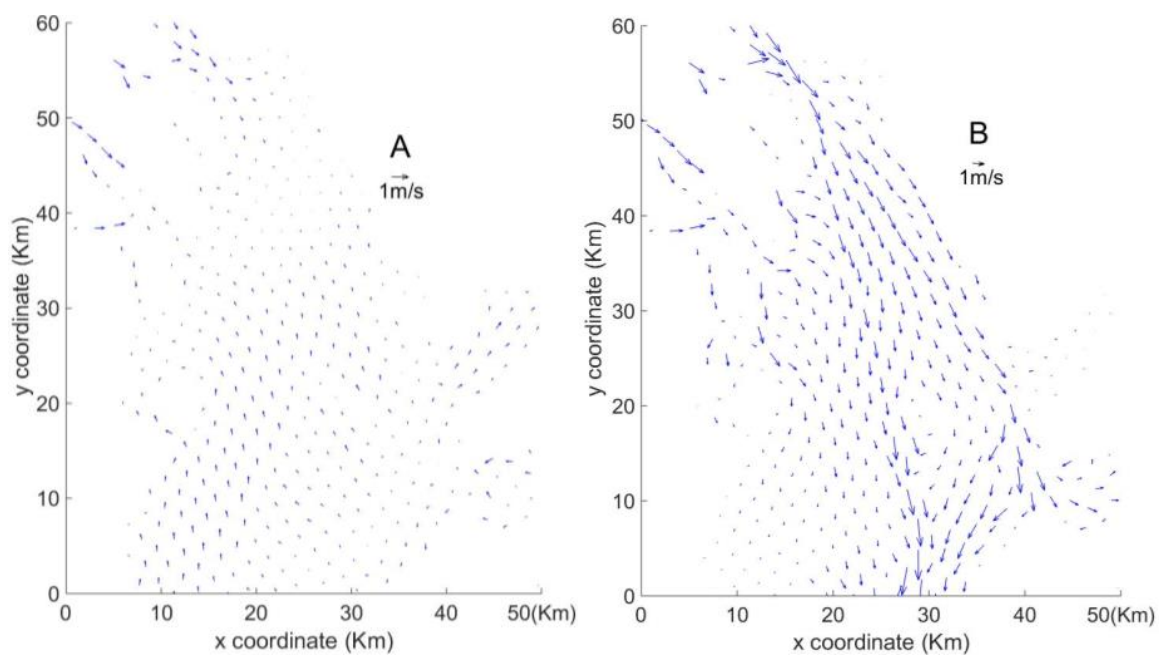

Figure 6. Current field of model (A: flood tide, B: ebb tide)

High saline water from continental shelf intruders along both sides of Hong Kong Island to LDY, and salinity of lower layer accounts for over 30\%o (Fig. 7). The tide intrusion front (also tide intrusion front) comes into being due to the large gradient of salinity and density. However, because of the difference of velocity and landforms due to shoal and trough in west shoal border zone of LDY, another front is generated.
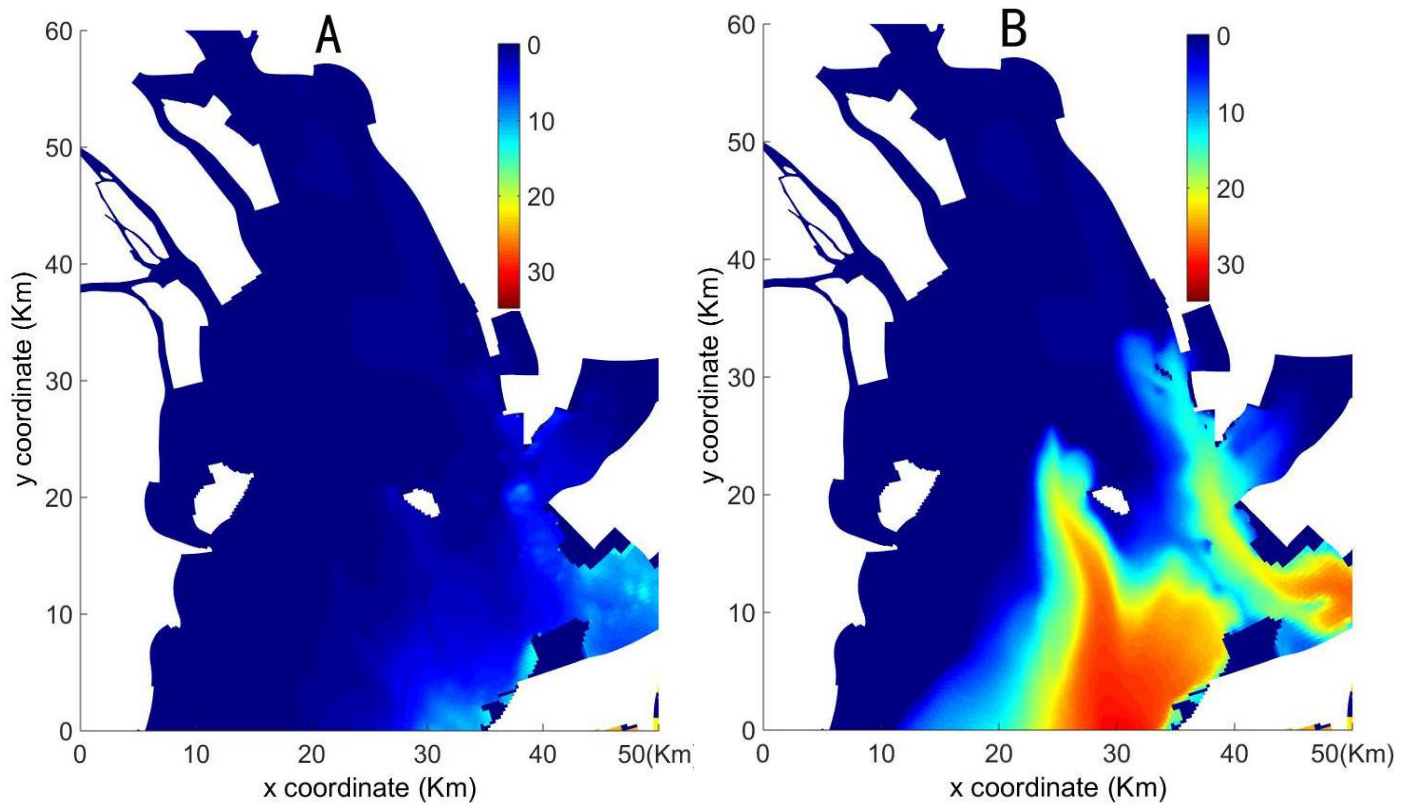

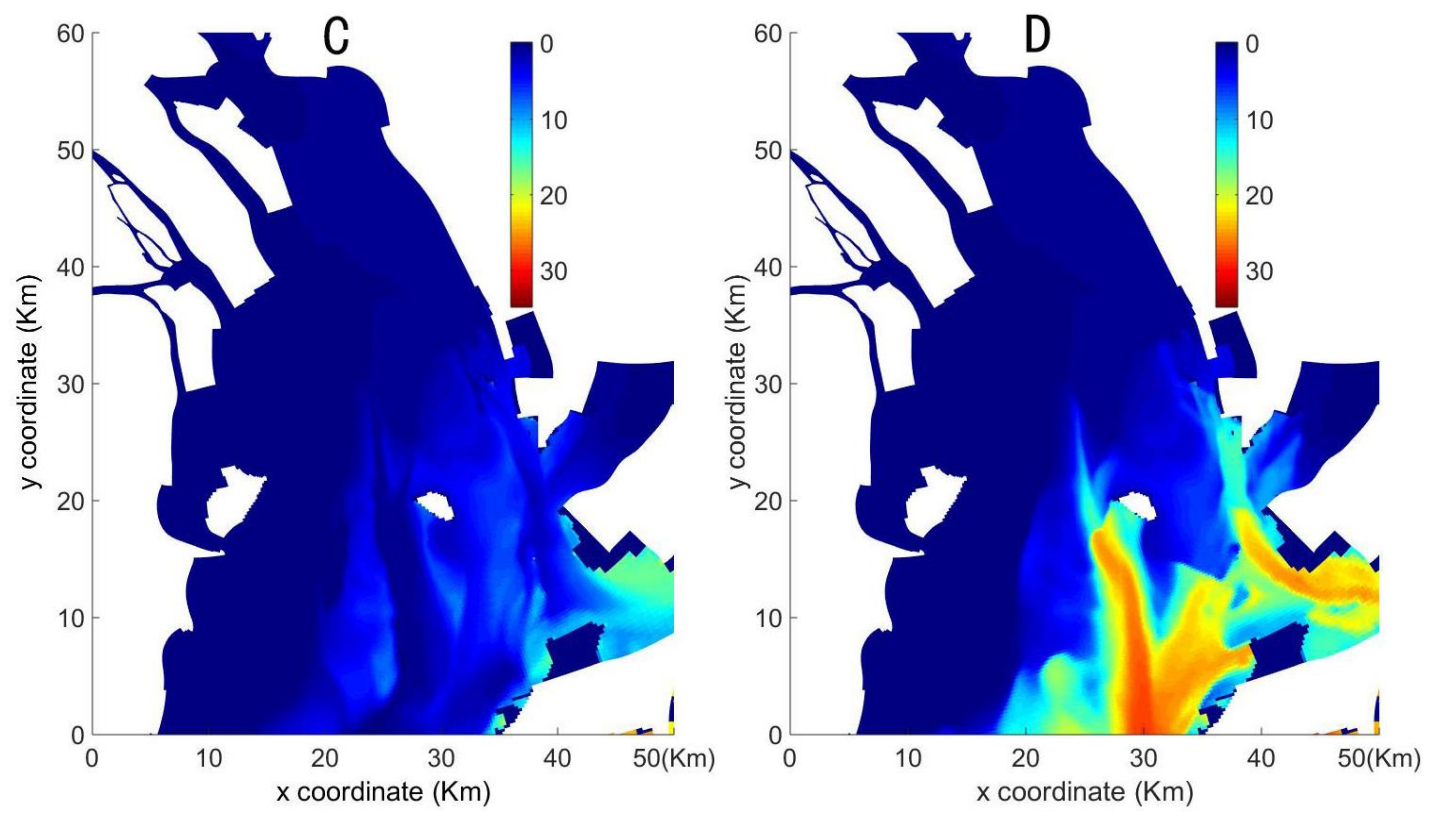

Figure 7. Salinity charts (\%o; A: surface, flood, B: bottom, flood, C: surface, ebb, D: bottom, $e b b)$

Based on the analysis above, the LDY can be divided into three type sub-areas of dynamic sedimentation, west area, jet-flow area, salt water area (Fig. 8). The west area is dominated by discharge from JM, HQM, HM, and flow seaward along West shoal into outer sea. Salt water area refers to the southeast of LDY, and the main characteristic is high salinity and density, resulting in three dimensionality of flow. Large part area of LDY is affected by jet-flow (Shilun, 1994) due to ebb current from HUM. The jet-flow structure is complicated, and evolves into plume flow in the end of jet-flow, which is suffered from salt water from middle and lower layer due to continental shelf water intrusion. So, fresh water from HUM flow seaward through upper layer.

Three dynamical structures interact through front (Figs. 9 and 10), resulting in control of water and sediment movement, also control the stability of main channel and sedimentation balance. According to the salinity, these dynamical structures correspond to three water mass, the fresh water, diluted water and sea water. The core part of the estuary is controlled by diluted water.

The diluted water mass is under the action of runoff discharge, and develops seaward in flood season. During the dry season, it recedes deeper into the land. In the dry season, the length of diluted water can reach $83 \mathrm{~km}$, while the flood season is below $40 \mathrm{~km}$. In above section of stagnation point, the kinetic is barotropic, and the net material is to transport seaward. In lower section of stagnation point, the pressure is baroclinic, and net material transport landward.

According to the surveying data, LDY is dominated by seaward flow. The velocity is faster and the duration is longer during the ebb period than in flood tide. The velocity of the middle and lower layers is greater than the surface downstream from the West shoal during the flooding period. During ebb, the surface velocity is the greatest. During both flood and ebb, the surface velocity upstream is greatest in surface, middle and bottom layers. Because flows from Lingding channel, North branch, and South branch of 
Jiaomen converge in the West shoal, surface velocity increases seaward during ebb. The majority of LDY was dominated by freshwater. Their middle and bottom layers were dominated by highly saline water from the shelf in the summer, especially during the flood period. The bottom maximum salinities of stations 4, 10 and 9 were, respectively, $22 \%$, $17.1 \%$, and $7.8 \%$ during the flood period, and the salinity of the rest stations was zero. Figure $7 B$ and $D$, illustrates the lower layer salinity of the lower section of the LDY. During the flood period, a salt wedge intrudes landward, and the salinity structure is highly stratified. This is referred to as the "tide inrush front" (Simpson and Turrell, 1986; Oyedotun, 2019).

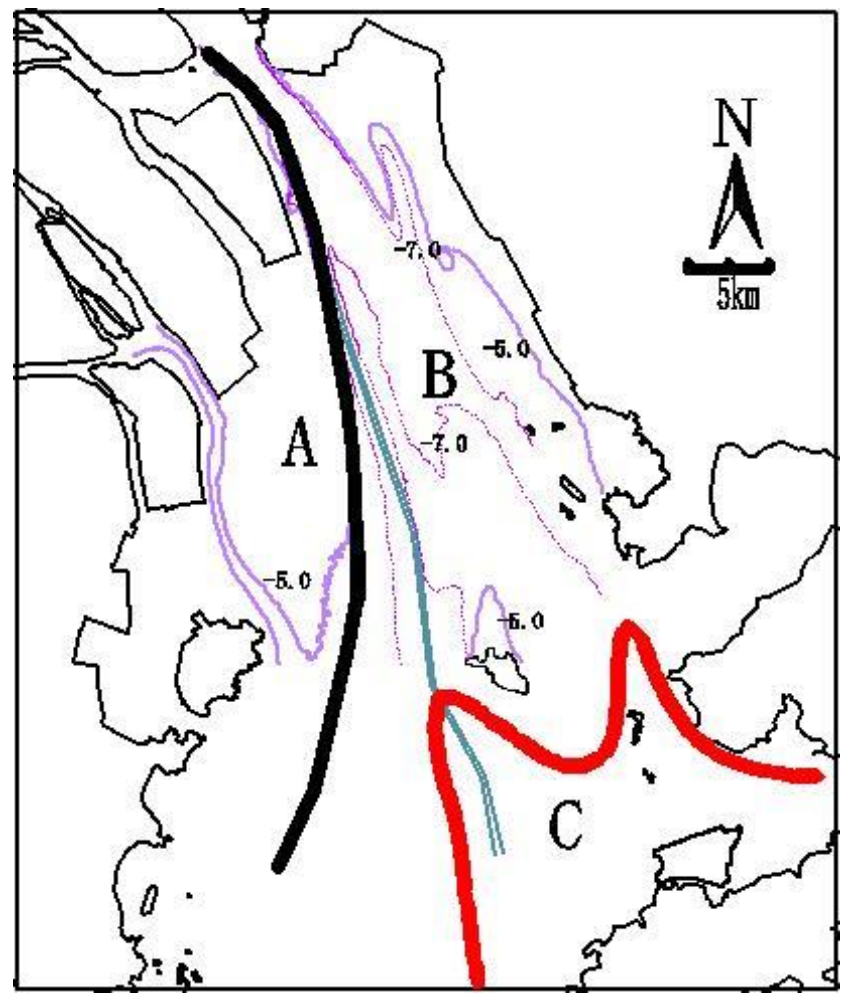

Figure 8. Dynamical subarea (the black broad line, estuarine front, the red broad line tide intrusion front, also saline wedge, A: fluvial area, B: jet-flow area, C: saline water area)

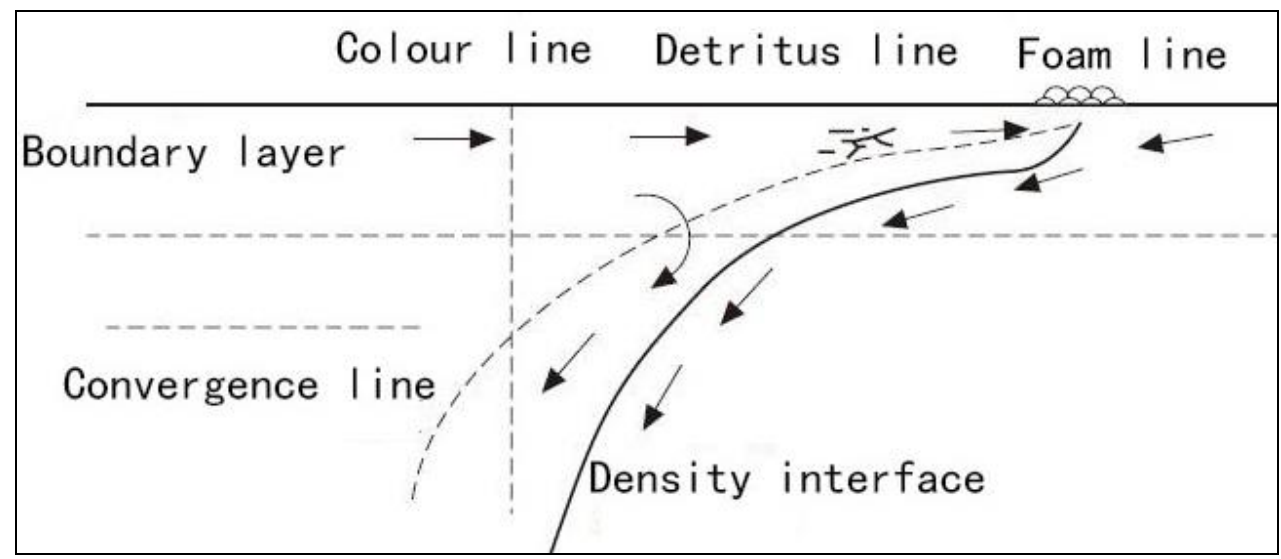

Figure 9. Schematic diagram of a vertical section perpendicular to a frontal convergence zone. (After Klemas and Polis, 1977; Ferrier, 1997) 


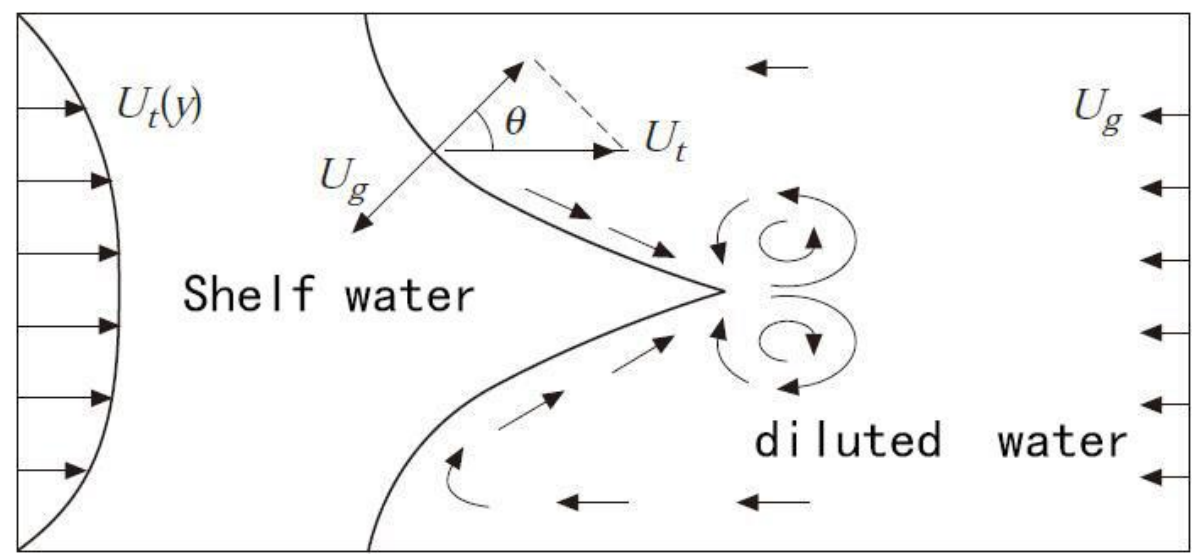

Figure 10. Schematic illustration of the interaction of tidal intrusion front with the lateral shear to produce a V-shaped front with a single point convergence at the apex and attendant gyres.

(After Simpson and Turrell, 1986; Ferrier, 1997)

\section{Front system and suspended sediment transportation}

Sediments, moving from river to sea, must pass through three hydrodynamic sections. The three sections are the river, near mouth, and estuary. The downstream limit of the river section is the tidal limit (Sanshanjiao), the near mouth section is the area between the tide limit and the tidal current limit (near the 21st Stream). The estuary section is the area between the tidal current limit and the front of the shelf water (near Hong Kong). These three sections play important roles in sediment transportation and deposition. When flow enters the tidal limit, the flow will be surfing from the reaction force of the tide and the longitudinal gradient of surface level will flatten out and flow velocity will decrease (Nouaim et al., 2019). As a result, the relative coarse silt group of suspended sediments will settle on the bed and because the transportation force has decreased, the coarse sand and gravel will be deposited. Field data regarding the first settlement ratio is not available but in the Yangtse River estuary, 10-15\% of suspended sediment will be deposited on the bed (Simpson and Nunes, 1981). Sediment that enters the estuary section suffers from bidirectional flow during flood and ebb periods. Sediment that is temporarily deposited on the bed during floods erodes due to ebb currents. Flow, which enters the West shoal, diffuses on the shoal surface, velocity declines and sediments deposit on the bed. The two flows from the West shoal and west channel converge at the edge of the West shoal and form a shear front (Figs. 11 and 12). Because of significant salt water invasion into the LDY from the middle and bottom layers, tide invasion fronts become important in the southeast area of LDY. Sediments in the front will settle again. According to the July 2005 data, about $3 \%$ of the total suspended sediment deposits, and the majority of the bed load is trapped. The ancient riverbed sand can be transported to the estuary from human agitation resulting from sand mining. SSC chart is shown in Figure 11, which show clearly transportation trend of suspended sediments in three water mass.

The silting content is high, and Mean percent content of stations $1,5,6,7,8$ is respectively $73.8 \%, 70 \%, 68.2 \%, 66.9 \%$ and $66.5 \%$, indicating that the percentage of silt decreases seaward (Table 3). Average silt percentage of stations 9 and 10 was $65.5 \%$ and $66.1 \%$, respectively, which is less than that of the West shoal. Silt content of suspended matter decreases seaward indicating that coarse sediments settle gradually 
during the transportation process, and suspended sediment becomes bed load. Surface velocity at ebb of stations 5, 6, and 4 increased longitudinally and the mean silt content decreased. Median diameter of bed sediment decreases seaward. Median particle diameters at stations $6,7,8$ and 4 were $0.071 \mathrm{~mm}, 0.068 \mathrm{~mm}, 0.026 \mathrm{~mm}$, and $0.026 \mathrm{~mm}$, respectively. The latitudinal change rule of median diameter and percentage of sand in bed sediment is related to the longitudinal variation. Median diameter and percentage of sand decreased from the West shoal to the west channel. Figure 12 is the SSC section of west channel, which illustrate that suspended sediments is transported through the upper layer of salt water area. Front systems and sediments transportation are shown in Figures 13 and 14.
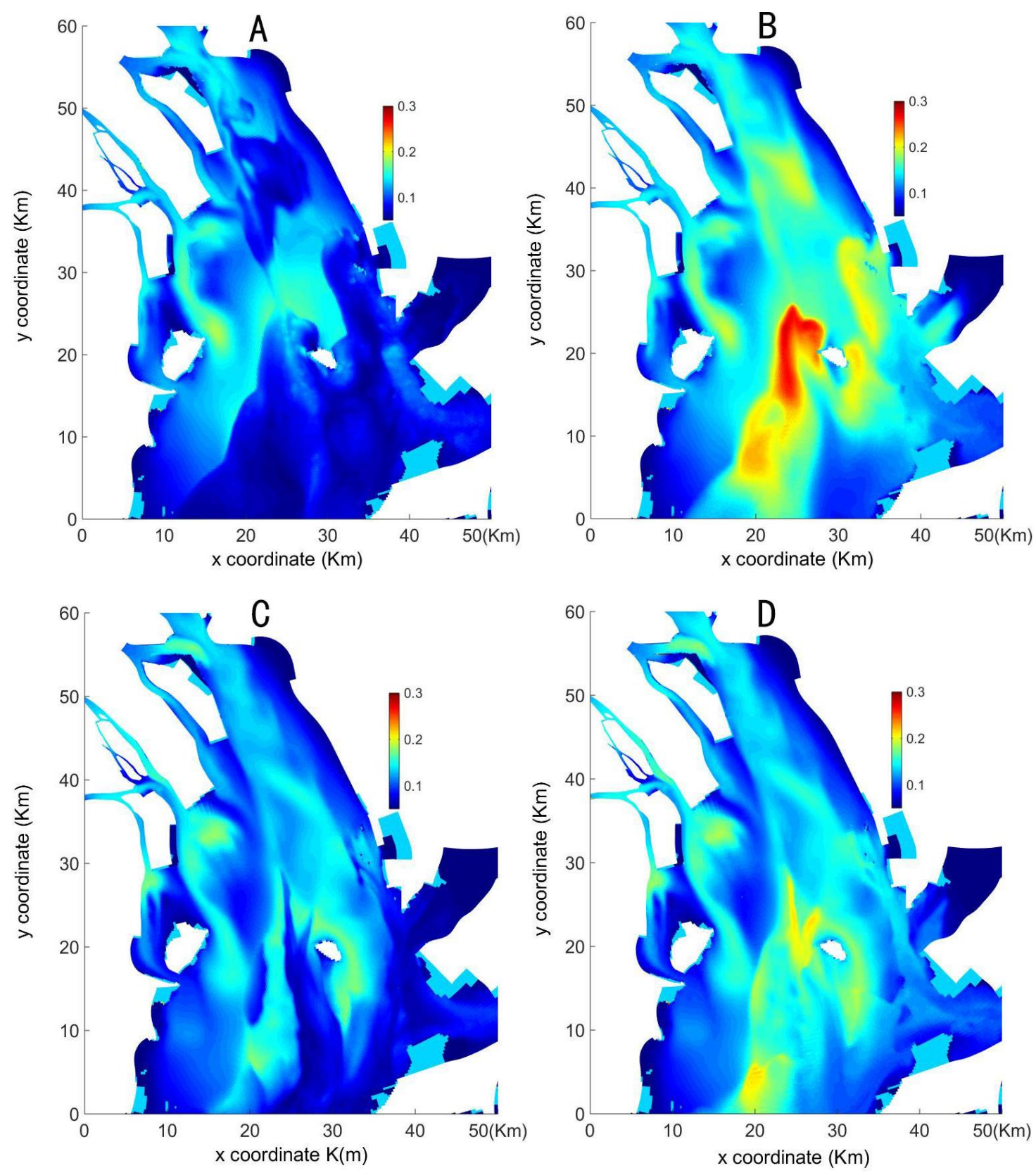

Figure 11. SSC chart $\left(\mathrm{kg} / \mathrm{m}^{3}, A:\right.$ flood, upper layer; B: flood, lower layer; $C$ : ebb, upper layer, D: ebb, lower layer) 

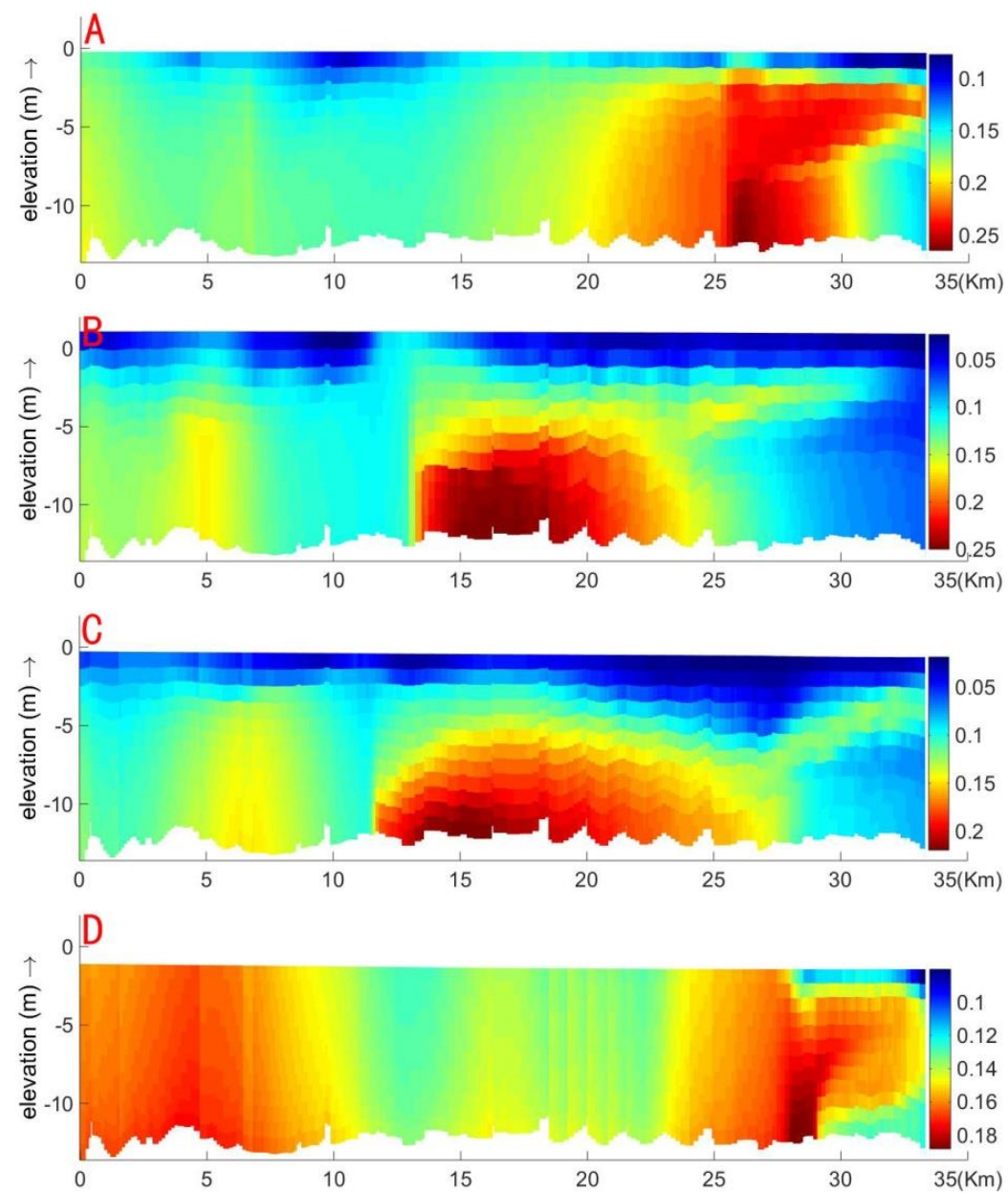

Figure 12. SSC section of Lingding navigation channel (A: flood period, B: flood slack, C: ebb period, D: ebb slack)

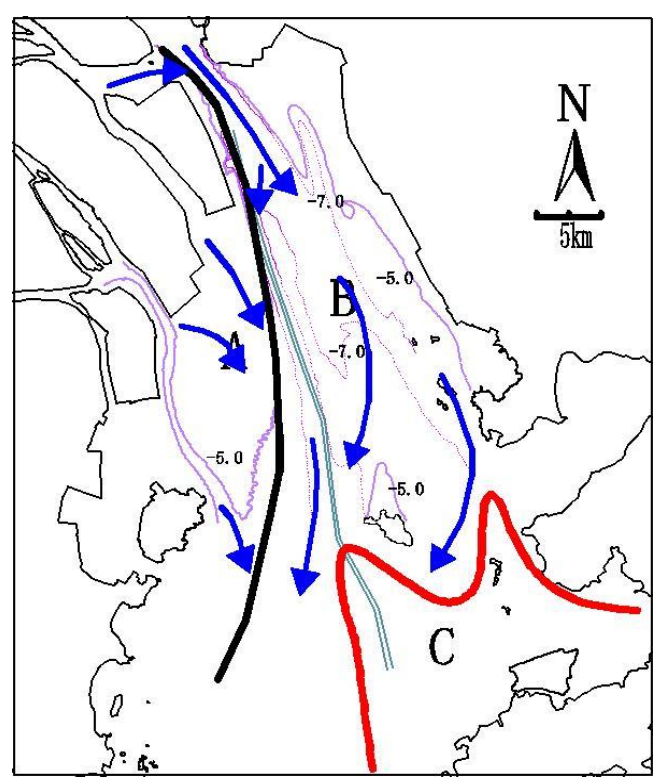

Figure 13. Front systems and sediments transportation (blue arrow: transportation orientation of cohesive sediment) 


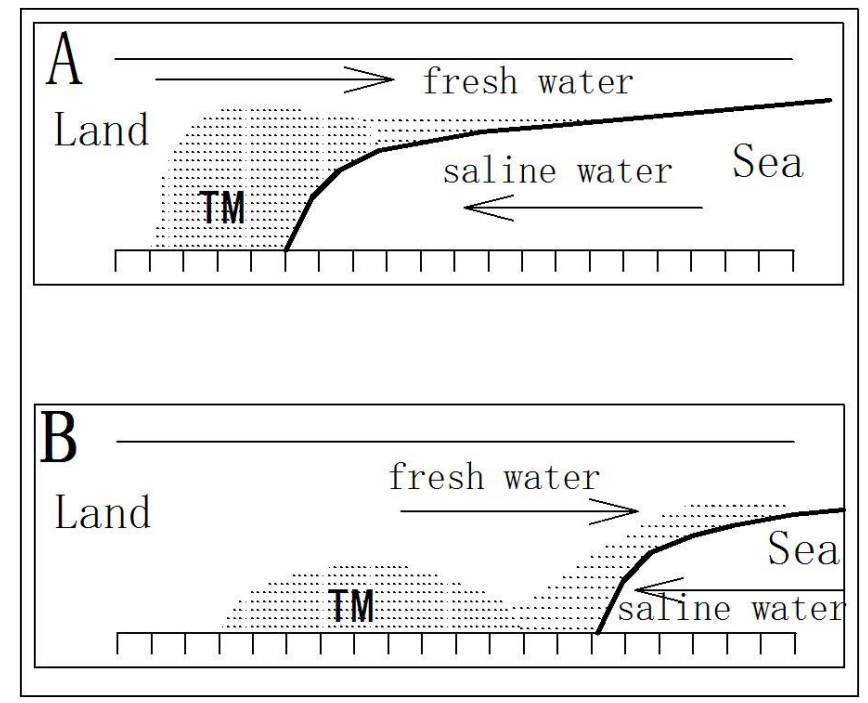

Figure 14. Conceptual model of estuarine circulation and sediment transportation (A: flooding tide, B: ebbing tide; TM: turbidity maximum)

Table 3. Percentages of fine sand and clay in suspended sediment

\begin{tabular}{c|c|c|c|c|c|c|c|c|c}
\hline \multicolumn{2}{c|}{ Items } & $\mathbf{1}$ & $\mathbf{5}$ & $\mathbf{6}$ & $\mathbf{7}$ & $\mathbf{8}$ & $\mathbf{4}$ & $\mathbf{9}$ & $\mathbf{1 0}$ \\
\hline \multirow{3}{*}{ Silt } & Mean & 73.8 & 70.0 & 69.3 & 68.2 & 66.9 & 66.5 & 65.5 & 66.1 \\
& Max & 87.3 & 67.7 & 72.4 & 74.9 & 70.6 & 76.0 & 65.5 & 67.4 \\
& Min & 62.0 & 59.6 & 57.4 & 57.4 & 56.8 & 52.1 & 51.8 & 51.4 \\
\hline \multirow{4}{*}{ Clay } & Mean & 26.2 & 30.0 & 30.7 & 31.8 & 33.1 & 33.5 & 34.5 & 33.9 \\
& Max & 38.0 & 40.4 & 42.6 & 42.6 & 43.2 & 47.9 & 48.2 & 48.6 \\
& Min & 12.7 & 32.3 & 27.6 & 25.1 & 29.4 & 24.0 & 34.5 & 32.6 \\
\hline
\end{tabular}

\section{Action of front systems on sedimentation}

Estuaries are located in the transition zone between rivers and the sea, and have zones or fronts which have significant impacts on sedimentation and pollutants. There are at least three types of fronts in LDY: tidal intrusion, headland, and shoal fronts (Talke et al., 2009). Based on charts of currents, landforms, and measured data, we propose the use of shear front instead of shoal front. The physical significance of a shear front is clearer than that of a shoal front. Figure 7 shows that there is salt wedge southeast of the LDY, which varies with ebb and flood (Yang, 2018). In fact, this is the tide intrusion front. Therefore, the tide intrusion front and the shear front become the main front system of the LDY. Fronts are formed by several mechanisms, including tidal intrusion, axial convergence, advective flow, and flow separation. Fronts act as temporary barriers, inhibit exchange of water masses, and entrap free particulate materials. We suggest that, in terms of suspended sediment transport through and within estuaries that are characterized by fronts, such features should be considered as "sieves" in the estuarine sediment transfer system (Townend, 2005). The "sieve" or trapping function for sediment is achieved by front systems of the estuary. Sediment transport characteristics of shear fronts include: (1) in a northerly direction, the surface water and sediments move downward, while in deeper water the sediments move upward; and (2) 
in a westerly direction, the surface water and sediments move into the channels, while in deeper water the sediments move into the shoals (Townend, et al., 2000). Therefore, the shear fronts between the shoals and the channel act as a barrier affecting the sediment deposition into the deep channel from the shoals (Uncles and Stephens, 1993). Fronts play an important role as barriers, traps, and filters for sediments. Sediments from the North branch will be trapped in an area near the shear front. The sedimentation rate of the region with 3-6 m depth is greater than in the region with depths $>6 \mathrm{~m}$. But, the shear front of the West shoal also has an erosion effect. During ebb periods, doublespiral circulation forms on both sides of the shear front, and, driven by longitudinal current, flows seaward with velocity greater than $1.0 \mathrm{~m} / \mathrm{s}$. The spiral flow will effectively scour the bed near the Lingding navigation channel. The secondary spiral flow associated with the front had the greatest influence on the lateral distribution of finer grains and the least influence on the lateral distribution of coarser grains (Uncles et al., 2006). So, the sedimentation rate of areas with 6-8 $\mathrm{m}$ depths is less than that of areas where the depth $<6 \mathrm{~m}$ (Fig. 15).

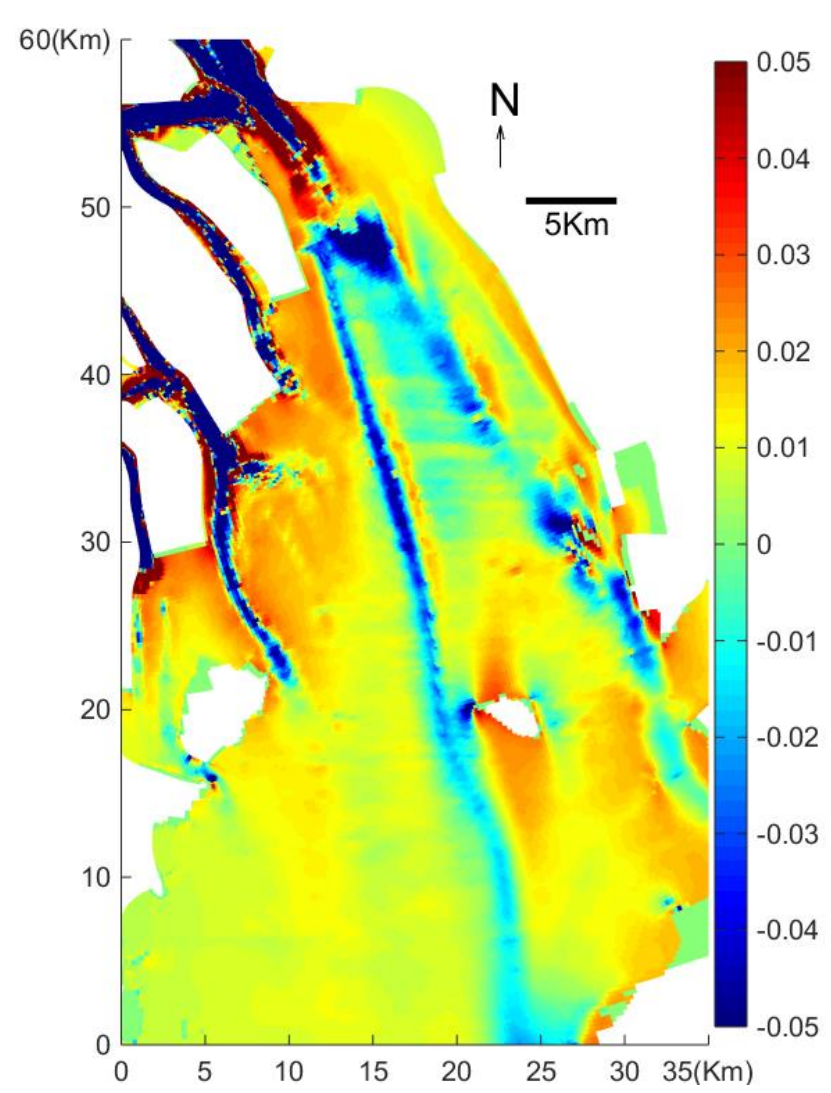

Figure 15. Depositional thickness of suspended sediment (m, half a year, from model result)

The tide intrusion front is located southeast of the LDY and varies with ebb and flood. The front penetrates landward under the water during flood, and the salinity structure is highly stratified. In addition, the front retreats seaward during ebb period. The formation and development of the tide intrusion front is opposite to that of the shear front. The functions of the tide intrusion front are similar to that of the shear front, which provides a barrier, filters, and traps material. However, the transportation function of this front is easy to underestimate. The West shoal is an important passage 
for fresh water, sediments, and pollutants. Materials from land are transported to sea along the front. The tide intrusion front also possesses the function of transportation, not by transport landward under water, but also transport seaward by the fresh water of the middle and top layers (Yang, 2018).

\section{Discussion}

Natural sediment sinks have been removed in many estuaries and tidal basins, and the resulting loss in accommodation space likely led to an increase in the suspended sediment concentration (Winterwerp et al., 2013). However, channel deepening also leads to higher SSC levels (Kang et al., 2018; Wu et al., 2003). Larger engineers such as reclamation, port construction, result in a reduction of the tidal prism, leading to smaller tidal flow velocities in the tidal channels, thereby promoting sediment deposition (Zhifu, 1995). Human activities have got attentions in Pearl River estuary (Zhifu, 1994) and Yangtze River estuary.

Economic development and human activity have had a large impact on the LDY estuary. The main human activities of LDY include reclamation, port construction, mining of bed sand, and channel dredging. The reclamation area includes $204 \mathrm{~km}^{2}$, which is $17 \%$ of the total area. Bed sand harvesting is up to 200 million $\mathrm{m}^{3}$, which is equivalent to $8 \%$ of the capacity of LDY.

Human removal of bed sediment for building construction has deepened the riverbed. After 2000, large-scale projects such as construction of the Lingding navigation channel and construction of the Nansha port near the West shoal will increase SSC. Because the front system of the West shoal can trap river-borne and sea-borne sediment, the sedimentation rate has increased after 2000 (Table 4). Although there were no human construction projects on the West shoal, the indirect impact of upstream and downstream projects on sedimentation has been significant.

Table 4. Sedimentation rate of west shoal

\begin{tabular}{c|c|c|c|c}
\hline Year & Depth & Area $\left(\mathbf{k m}^{2} / \mathbf{a}\right)$ & Volume $\left(\right.$ Ten th. $\left.\mathbf{~ m}^{\mathbf{3}} / \mathbf{a}\right)$ & Sed. rate $(\mathbf{c m} / \mathbf{a})$ \\
\hline & $>-2$ & 0.3763 & 15.46 & 0.60 \\
& $-2 \sim-3$ & 0.2987 & 41.82 & 1.00 \\
& $-3 \sim-4$ & 0.5881 & 100.45 & 3.40 \\
2000 2005 & $-4 \sim-5$ & 0.0023 & 128.03 & 5.00 \\
& $-5 \sim-6$ & -0.3921 & 125.79 & 4.30 \\
& $-6 \sim-7$ & -0.7358 & 24.84 & 1.10 \\
& $-7 \sim-8$ & 0.1593 & 26.4 & 3.00 \\
\hline \multirow{5}{*}{ 1986 2000 } & $>-2$ & -0.064 & 3.71 & 0.10 \\
& $-2 \sim-3$ & 0.4292 & 9.06 & 0.20 \\
& $-3 \sim-4$ & 0.1072 & 41.48 & 1.60 \\
& $-4 \sim-5$ & 0.052 & 52.84 & 2.10 \\
& $-5 \sim-6$ & -0.0257 & 52.24 & 1.70 \\
& $-6 \sim-7$ & -0.5246 & 29.4 & 1.10 \\
& $-7 \sim-8$ & -0.2024 & -13.86 & -1.80 \\
\hline
\end{tabular}




\section{Conclusion}

The LDY is a complex tidal bay, which has two main front systems, tide intrusion front and shear front. These two front systems divided the LDY into three dynamics area, west shoal area, jet-flow area, salinity water area. Sediment transport and deposition processes of the three areas differ (Dager, 2017). Silting characteristics include shoal silting and channel deepening. Sediment transportation and sedimentation are subject to front systems, which sedimentary facies is corresponding to. Human activities such as river estuary regulation and channel dredging increase SSC, which leads to promote sediment deposition. The amount of sediment deposition has greatly increased since 2000.

It can be seen that human activities such as estuary regulation and river dredging are important factors for increasing sediment deposition, and the increasing sediment deposition will make the imbalance of sediment transport more prominent. In order to improve navigation conditions and reduce siltation under sluice gates, measures such as drainage, mechanical dragging and tidal scouring can be taken.

Acknowledgements. The study was supported by the Natural Science Foundation (41406005). We thank the hydrology and water resources survey bureau of the Yangtze River Water Conservancy Committee, which completed the work of field observation. We thank LetPub for its linguistic assistance during the preparation of this manuscript.

\section{REFERENCES}

[1] Allen, G. P., Salomon, J. C., Bassoullet, P., Du Penhoat, Y., De Grandpre, C. (1980): Effects of tides on mixing and suspended sediment transport in macrotidal estuaries. Sediment Geol 26: 69-90.

[2] Cameron, G., Prichard, D. (1963): Estuaries. - In: Hill, M. N. (ed.) The Sea. Wiley, New York, pp. 306-324.

[3] Chen, J., Li, D., Chen, B., Hu, F., Zhu, H., Liu, C. (1999): The processes of dynamic sedimentation in the Changjiang Estuary. - Journal of Sea Research 41(1-2): 129-140.

[4] Dager, M. R. (2017): 1. Composición de la materia orgánica, $\mathrm{pH}$, intercambio catiónico y textura de cinco suelos ubicados entre 670 y $1600 \mathrm{msnm}$ en la cuenca del río Maracay, Venezuela. - Revista de la Facultad de Agronomia de la Universidad del Zulia 34(2).

[5] Dai, Z. J., Du, J. Z., Zhang, X. L., Su, N., Li, J. F. (2011a): Variation of riverine matrial loads and environmental consequences on the Changjiang estuary in recent decades. Environmental Science and Technology 45: 223-227.

[6] Dai, Z. J., Du, J. Z., Chu, A., Zhang, X. L. (2011b): Sediment characteristics in the North Branch of the Yangtze Estuary based on radioisotope tracers. - Environmental Earth Sciences 62: 1629-11634.

[7] Dai, Z., Chu, A., Stive, M. J., Yao, H. (2012): Impact of the Three Gorges Dam overruled by an extreme climate hazard. - Natural Hazards Review 13(4): 310-316.

[8] Dai, Z. J., Chu, A., Li, W. H., Li, J. F., Wu, H. L. (2013): Has suspended sediment concentration near the mouth bar of the Yangtze (Changjiang) Estuary been declining in recent years? - Journal of Coastal Research 29(4): 809-818.

[9] Dalrymple, R. W., Zaitlin, B. A., Boyd, R. (1992): Estuarine facies models; conceptual basis and stratigraphic implications. - Journal of Sedimentary Research 62(6): 11301146. 
[10] Daniel, G. I., Henry, O. U., Ayodeji, B. B., Silas, M. Y. (2018): Land suitability analysis for the production of Cocoyam Inbenue State, Nigeria. - Earth Sciences Malaysia 2(2): 25-30.

[11] Dellwig, O., Hinrichs, J., Hild, A., Brumsack, H. J. (2000): Changing sedimentation in tidal flat sediments of the southern North Sea from the Holocene to the present: a geochemical approach. - Journal of Sea Research 44: 195-208.

[12] Duck, R. W., Wewetzer, S. F. K. (2001): Impact of frontal systems on estuarine sediment and pollutant dynamics. - The Science of the Total Environment 266: 23-31.

[13] Dyer, K. R. (1988): Fine Sediment Particle Transport in Estuaries. - In: Dronkers, J., van Leussen, W. (eds.) Physical Process in Estuaries. Springer, Berlin, pp. 427-445.

[14] Ferriera, G. J., Anderson, M. (1997): A multi-disciplinary study of frontal systems in the Tay Estuary, Scotland. - Estuarine, Coastal and Shelf Science 45: 317-336.

[15] Fettweis, M., Monbaliu, J., Baeye, M., Nechad, B., Van den Eynde, D. (2012): Weather and climate induced spatial variability of surface suspended particulate matter concentration in the North Sea and the English Channel. - Methods Oceanogr 3(4): 2539.

[16] Grabemann, I., Uncles, R. J., Krause, G., Stephens, J. A. (1997): Behaviour of turbidity maxima in the Tamar (UK) and Weser (FRG) estuaries. - Estuar. Coast. Shelf Sci. 45: 235-246.

[17] Hume, T. M., Herdendorf, C. E. (1988): A geomorphic classification of estuaries and its application to coastal resource management - a New Zealand example. - Ocean Shoreline Manag 11(3): 249-274.

[18] Jalón-Rojas, I., Schmidt, S., Sottolichio, A. (2015): Turbidity in the fluvial Gironde Estuary (southwest France) based on 10-year continuous monitoring: sensitivity to hydrological conditions. - Hydrology and Earth System Sciences 19(6): 2805-2819.

[19] Jalón-Rojas, I., Schmidt, S., Sottolichio, A. (2017): Comparison of environmental forcings affecting suspended sediments variability in two macrotidal, highly-turbid estuaries. - Estuarine, Coastal and Shelf Science 198: 529-541.

[20] Jia, L. W., Pan, S. Q., Wu, C. Y. (2013): Effects of the anthropogenic activities on the morphological evolution of the Modaomen Estuary, Pearl River Delta, China. - China Ocean Engineering 27(6): 795-808.

[21] Jiang, S., Lian, M., Lu, C., Gu, Q., Ruan, S., Xie, X. (2018): Ensemble prediction algorithm of anomaly monitoring based on big data analysis platform of open-pit mine slope. - Complexity 2018.

[22] Kang, L.; Du, H. L.; Du, X.; Wang, H. T.; Ma, W. L.; Wang, M. L.; Zhang, F. B. (2018): Study on dye wastewater treatment of tunable conductivity solid-waste-based composite cementitious material catalyst. - Desalination and Water Treatment 125: 296-301.

[23] Largier, J. L. (1992): Tidal intrusion fronts. - Estuaries 15(1): 26-39.

[24] Le Hir, P., Ficht, A., Jacinto, R. S., Lesueur, P., Dupont, J. P., Lafite, R., Cugier, P. (2001): Fine sediment transport and accumulations at the mouth of the Seine estuary (France). - Estuaries 24(6): 950-963.

[25] Li, C. C. (2004): Estuarine Process and Evolution Pattern in South China. - Science Press, Beijing 9: 80-91.

[26] Li, M. G., Shi, Z., Qin, C. R. (2003): Three dimensional suspended sediment movement simulation of the Ligdingyang Bay. - Shuili Xuebao 4: 51-56.

[27] Lick, W., Lick, J., Ziegler, C. (1994): The resuspension and transport of fine-grained sediments in Lake Erie. - Journal of Great Lakes Research 20(4): 599-612.

[28] Lick, W., Xu, Y. J., McNeil, J. (1995): Resuspension properties of sediments from the Fox, Saginaw, and Buffalo Rivers. - Journal of Great Lakes Research 21(2): 257-274.

[29] Lu, Y. J., Li, H. L., Wang, H. C., Zuo, L. Q. (2005): Back silting and regulation of waterway with sand bar in strong tidal estuary. - Shuili Xuebao (Journal of Hydraulic Engineering) 36(12): 1450-1456. 
[30] Nouaim, W., Chakiri, S., Rambourg, D., Karaoui, I., Ettaqy, A., Chao, J., Allouza, M., Razoki, B., Yazidi, M., Hmidi, F. E. (2019): Mapping the water erosion risk in the Lakhdar river basin (central High Atlas, Morocco). - Geology, Ecology, and Landscapes 3(1): 22-28.

[31] Nwankwoala, H. O. (2019): Geoethics as an emerging discipline: perspectives, ethical challenges and prospects. - Earth Sciences Malaysia 3(1): 01-08.

[32] Omini, E. O., Akpang, O. M. (2018): Cavity detection under re-enforced concrete floor using ground penetration radar. - Engineering Heritage Journal 2(2): 11-18.

[33] Oyedotun, T. D. T. (2019): Land use change and classification in Chaohu Lake catchment from multi-temporal remotely sensed images. - Geology, Ecology, and Landscapes 3(1): 37-45.

[34] Pinckney, J., Dustan, P. (1990): Ebb-tidal fronts in Charleston Harbor, South Carolina: physical and biological characteristics. - Estuaries 13(1): 1-7.

[35] Pritchard, D. W. (1967): What is an Estuary: Physical Viewpoint. - In: Lauff, G. H. (ed.) Estuaries. American Association for the Advancement of Science, Washington, pp. 3-5.

[36] Qiao, F. (2018): The study on the integration of green architecture and appropriate technology. - Engineering Heritage Journal 2(2): 01-03.

[37] Rahim, Y., Khan, M. S., Mughal, S. (2018): Petrography of sandstone of the Lumshiwal Formation from eastern Hazara, Khyber Pakhtunkhwa, Pakistan: implications for provenance, diagenesis and environments of deposition. - Earth Sciences Pakistan 2(2): 01-06.

[38] Reeves, A. D., Duck, R. W. (2001): Density fronts: Sieves in the estuarine sediment transfer system? - Physics and Chemistry of the Earth, Part B: Hydrology, Oceans and Atmosphere 26(1): 89-92.

[39] Ren, J., Bao, Y., Lin, W. Q. (2001): Analyseson water and suspended sediment fluxes in ling ding yang estuary of Zhu Jiang River mouth. - Journal of Tropical Oceanography 3: 31-40.

[40] Ren, J., Wu, C. C., Bao, Y. (2006): Dynamic structure of Humen estuary of the Pearl River. - Acta Scientiarum Naturalium Universitatis Sunyatseni 45(3): 105-109.

[41] Ren, J., Zeng, X. Z., Jia, L. W. (2010): Mechanism study of retrogressive erosion in the lower Reach of Dongjiang River. - Advances in Water Science 21(1): 84-88.

[42] Sarker, M. K. U., Majumder, A. K., Haque, M. Z., Hossain, M. S., Nayeem, A. A. (2019): Assessment of inland water quality parameters of Dhaka City, Bangladesh. Environment \& Ecosystem Science 3(1): 13-16.

[43] Sarwar, M. T., Hui, Z. H., Maqbool, A. (2019): Causes and control measures of urban air pollution in China. - Environment \& Ecosystem Science 3(1): 35-36.

[44] Savenije, H. H. (2006): Salinity and Tides in Alluvial Estuaries. - Elsevier, Amsterdam.

[45] Sharjeel, A., Anwar, S., Nasir, A., Rashid, H. (2019): Design, development and performance of optimum water softener. - Earth Sciences Pakistan 3(1): 23-28.

[46] Shi, J. Z. (2010): Tidal resuspension and transport processes of fine sediment within the river plume in the partially-mixed Changjiang River estuary, China: a personal perspective. - Geomorphology 121: 133-151.

[47] Shilun, Y. (1994): Statistical regularity of particle size parameters and hydrodynamic explanation in Yangtse River estuary. - Sediment Research 3: 23-31.

[48] Simpson, J. H., Nunes, R. A. (1981): The tidal intrusion front: an estuarine convergence zone. - Estuarine and Coastal Shelf Science 13: 257-266.

[49] Simpson, J. H., Turrell, W. R. (1986): Convergent Fronts in the Circulation of Tidal Estuaries. - In: Wolfe, D. A. (ed.). Estuarine Variability. Academic Press, New York.

[50] Talke, S. A., Swart, H. E., Schuttelaars, H. M. (2009): Feedback between residual circulations and sediment distribution in highly turbid estuaries: an analytical model. Cont. - Shelf Res 29: 119-135.

[51] Townend, I. (2005): An examination of empirical stability relationships for UK estuaries. - Journal of Coastal Research 21(5): 1042-1053. 
[52] Townend, I., Wright, A., Price, D. (2000): An investigation of the gross properties of UK estuaries. - Modelling Estuary Morphology and Process. Report prepared by the EMPHASYS Consortium for the Estuaries Research Programme Phase 1, MAFF Project FD1401.

[53] Uncles, R. J., Stephens, J. A. (1993): The freshwater-saltwater interface and its relationship to the turbidity maximum in the Tamar Estuary, United Kingdom. - Estuaries and Coasts 16(1): 126-141.

[54] Uncles, R. J., Stephens, J. A., Law, D. J. (2006): Turbidity maximum in the macro-tidal, highly turbid Humber Estuary, UK: flocs, fluid mud, stationary suspensions and tidal bores. - Estuar. Coast. Shelf Sci. 67: 30-52.

[55] Van Maren, D. S., Oost, A. P., Wang, Z. B., Vos, P. C. (2016): The effect of land reclamations and sediment extraction on the suspended sediment concentration in the Ems Estuary. - Marine Geology 376: 147-157.

[56] Williams, J., Lee, G. H., Shin, H. J., Dellapenna, T. (2015): Mechanism for sediment convergence in the anthropogenically altered microtidal Nakdong Estuary, South Korea. - Marine Geology 369: 79-90.

[57] Winterwerp, J. C., Wang, Z. B., Van Braeckel, A., Van Holland, G., Kösters, F. (2013): Man-induced regime shifts in small estuaries-I: a comparison of rivers. - Ocean Dyn 63(11-12): 1293-1306.

[58] Wu, J., Zhang, S., Ren, L. (2003): Field observations of current and suspended sediment concentration during sediment disposal in the Changjiang (Yangtze) Estuary. - Acta Oceanologica Sinica 25(4): 91-103.

[59] Yang, B., Luo, Y., Jeng, D., Feng, J., Huhe, A. (2018a): Experimental studies on initiation of current-induced movement of mud. - Applied Ocean Research 80: 220-227.

[60] Yang, B., Gao, F. P., Jeng, D. S. (2018b): Failure mode and dynamic response of a double-sided slope with high water content of soil. - Journal of Mountain Science 15(4): 859-870.

[61] Zhifu, Y. (1994): The frontal classification and its influence on sedimentation in lingdingyang, zhu jiang river estuary. - Journal of Tropical Marine 13: 25-32.

[62] Zhifu, Y. (1995): A study on notable features of sedimentary dynamics in Lingdingyang estuary of Zhujiang River. - Tropicoceanology 14(2): 76-82. 